\title{
Contourite identification along Italian margins: The case of the Portofino drift (Ligurian Sea)
}

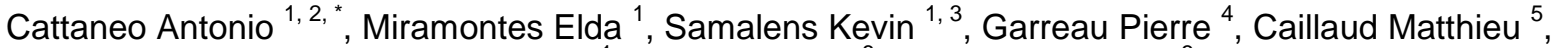 \\ Marsset Bruno ${ }^{1}$, Corradi Nicola ${ }^{6}$, Migeon Sebastien ${ }^{3}$
}

${ }^{1}$ IFREMER, Géosciences Marines, Z.I. Pointe du Diable, BP70, Plouzané, France

2 CNR-ISMAR, via Gobetti 101, 40129, Bologna, Italy

${ }^{3}$ GEOAZUR, UMR7329, 250 rue A. Einstein, 06560 Valbonne, France

${ }^{4}$ IFREMER, UMR LOPS, Z.I. Pointe du Diable, BP70, Plouzané, France

${ }^{5}$ IFREMER, DYNECO, Z.I. Pointe du Diable, BP70, Plouzané, France

${ }^{6}$ Università di Genova, DISTEV, Corso Europa 26, 16132 Genova, Italy

* Corresponding author : Antonio Cattaneo, email address : antonio.cattaneo@ifremer.fr

\begin{abstract}
:
A brief review of the published evidence of current deposits around Italy is the occasion to test the robustness of matching bottom current velocity models and seafloor morphologies to identify contourite drifts not yet documented. We present the result of the regional hydrodynamic model MARS3D in the Northern Tyrrhenian and Ligurian Sea with horizontal resolution of $1.2 \mathrm{~km}$ and 60 levels with focus on bottom current: data are integrated over summer and winter 2013 as representative of low and high intensity current conditions.
\end{abstract}

The Eastern Ligurian margin is impacted by the Levantine Intermediate Water (LIW) with modeled mean velocity of bottom current up to $20 \mathrm{~cm} \mathrm{~s}-1$ in winter 2013 and calculated bottom shear stress exceeding $0.2 \mathrm{~N} \mathrm{~m}-2$ in water depth of $400-800 \mathrm{~m}$. By crossing this information with seafloor morphology and geometry of seismic reflections, we identify a sediment drift formerly overlooked at ca $1000 \mathrm{~m}$ water depth. The Portofino separated mounded drift has a maximum thickness of at least $150 \mathrm{~m}$ and occurs in an area of mean current velocity minimum. Independent evidence to support the interpretation include bottom current modelling, seafloor morphology, seismic reflection geometry and sediment core facies. The adjacent areas impacted by stronger bottom currents present features likely resulted from bottom current erosion such as a marine terrace and elongated pockmarks.

Compared to former interpretation of seafloor morphology in the study area, our results have an impact on the assessment of marine geohazards: submarine landslides offshore Portofino are small in size and coexist with sediment erosion and preferential accumulation features (sediment drifts) originated by current-dominated sedimentary processes. Furthermore, our results propel a more general discussion about contourite identification in the Italian seas and possible implications. 


\section{Graphical abstract}

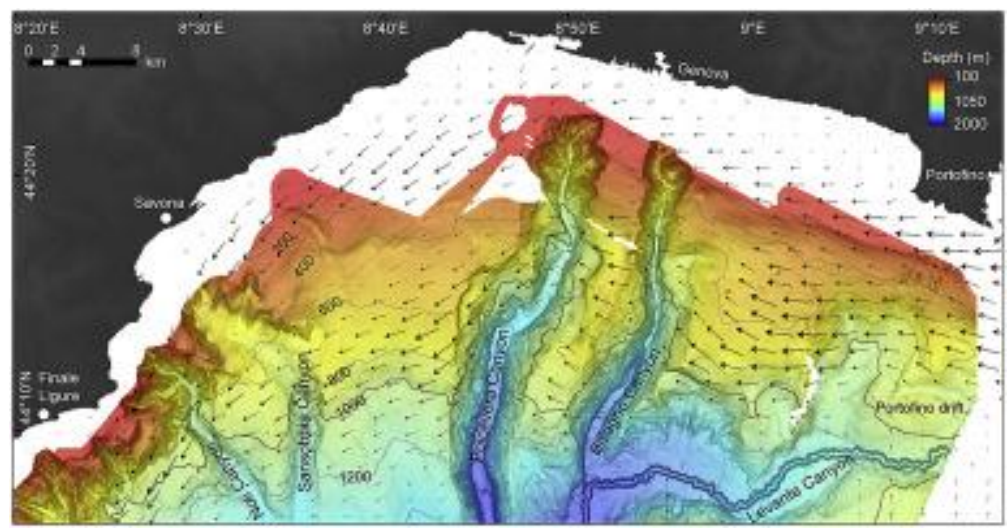

\section{Highlights}

Over the last ten years studies on contourites around Italy multiplied. The MARS3D circulation model shows a vein of LIW reaching the Ligurian margin. S Superposing bottom current velocity and morphology helps identify contourites. The Portofino mounded drift in $1000 \mathrm{~m}$ w.d. is immediately downslope of the LIW. Evidence of erosion and mass wasting is present within and nearby the drift.

Keywords : Sediment drift, Circulation model, Bottom current velocity, Levantine Intermediate Water, Submarine landslide, Mediterranean 


\section{INTRODUCTION}

Contourites are defined as the sediment deposited or substantially reworked by the persistent action of bottom currents (Stow et al., 2002; Rebesco et al., 2014). The increasing role assigned to bottom current in shaping continental margin has emerged over the last decade with the recognition of the effects of dense water plunging in confined canyon systems (e.g., Canals et al., 2006) or in the search of dense water paths and their traces in areas of dense water formation (e.g., Chiggiato et al., 2016; Tripsanas et al., 2016 in the Mediterranean).

Recent studies on contourites proved the effectiveness of crossing physical oceanographic and geomorphological approaches for the identification of contourites (e.g., Hernández Molina et al., 2016). The analysis of water masses characteristics and the coupling with observed seafloor morphology (marine terraces, mounded morphologies) suggest that the role of bottom currents and internal waves could be dominant over large areas of the Mediterranean, as for example in the Alboran Sea (Ercilla et al., 2016).

Also around Italian coastlines there is an increasing number of scientific contributions on contourite deposits since the first interpretation of mounded morphologies with peculiar internal geometry in the southern Adriatic Sea, Sicily channel and Corsica trough (Marani et al., 1993). To date, deposits directly linked to the action of bottom currents are reported in at 
least 16 locations around Italy (Fig. 1, Tab. 1). Due to their basin-wide occurrence, we did not include in Figure 1 and Table 1 a class of potential contourites, the so called 'shelf contourites' (Verdicchio and Trincardi, 2008a). These shelf contourites, or 'coastal mud wedges', show an asymmetric distribution downslope and downcurrent of major Mediterranean and Italian deltas (Cattaneo et al., 2004, 2007), and have relevant implications in the comprehension of sediment transport (Milligan and Cattaneo, 2007) and deformation (Berndt et al., 2006; Urgeles et al., 2011).

In the Adriatic Sea, two groups of contouritic sediment bodies exist: those linked to the formation and cascading of dense waters in the Northern Adriatic (Trincardi et al., 2007; Chiggiato et al., 2016; Foglini et al., 2016) and those formed by the action of Levantine Intermediate Waters (LIW; Verdicchio and Trincardi, 2006, 2008b). In the Ionian Sea, the identification of drifts proceeded in parallel with the discovery of living deep coral communities dwelling in current-impacted sites (Taviani et al., 2005, 2016). In the Sicily Channel, the presence of contourite deposits highlights the role of flow restrictions in accelerating currents and effectively shaping seafloor morphologies (Marani et al., 1993; Reeder et al., 2002; Martorelli et al., 2011). In the Tyrrhenian Sea, contourites are reported in correspondence of promontories and islands (Martorelli et al., 2010, 2016). In the Corsica trough, Roveri (2002) proposed an evolutionary model of sediment drift successively refined and supported with chronological constraints by Miramontes et al. (2016a): here contourites owe their location and morphology to inherited topography and bottom current distribution, and their internal stratigraphic architecture to glacioeustatic tuning.

In spite of the remarkable match of LIW current path and contourite drift occurrences (Fig. 1 ), there are long stretches of the Italian margins where contourites are not reported. Here our purpose is to present for the first time a superposition of bottom current pattern and morphological evidence to unveil the presence of contourites along the Ligurian margin.

\section{REGIONAL SETTING}

\subsection{Oceanography}

The three main water masses present along the Ligurian margin are the Atlantic Water (AW), the Levantine Intermediate Water (LIW), and the Western Mediterranean Deep Water (WMDW; Figs. 1, 2). The AW is found at water depths ranging from 0 to $200 \mathrm{~m}$ (Millot and Taupier-Letage, 2005; Millot, 2009). The LIW is formed in the Eastern Mediterranean by a process of evaporation during the summer, resulting in a warm and salty surface water mass that cools in winter and sinks in February-March (Lascaratos et al., 1999). It then enters in the Tyrrhenian Sea through the Sicily channel where it is found between 200 and 600-1000 m. Afterwards, it flows northwards through the Corsica trough towards the Ligurian margin 
(Artale and Gasparini, 1990). The Western Mediterranean Deep Water (WMDW) is mainly formed in the Gulf of Lions by surface cooling and evaporation due to cold and dry northern winds and open-sea convection (Durrieu de Madron et al., 2013). This water mass is present in the deep basins of the Western Mediterranean Sea, including the deepest part of the Tyrrhenian Sea. In the Ligurian Sea, the upper $150 \mathrm{~m}$ are characterised by the presence of the AW, above the LIW. The WMDW is on average present below $1000 \mathrm{~m}$ water depth (Millot, 2009; Pinardi et al., 2015).

The main oceanographic feature affecting the Ligurian margin is the Northern Current, a branch of the general North-Western Mediterranean cyclonic circulation extending from the Ligurian to the Catalan Sea and marked by a strong seasonal variability (Pinardi et al., 2015): in winter and early spring, instabilities of this slope current are intense and generate eddies, meanders and filaments.

\subsection{Geological and morphologic setting}

The Ligurian margin originated during the opening of Western Mediterranean basins initiated some $30 \mathrm{Myr}$ ago within the general context of the convergence of Eurasian and African plates (Jolivet and Faccenna, 2000). It is a passive margin in the back arc area of the Northern Apennine chain (Rollet et al., 2002) and it is presently reactivated in compression as testified by GPS measurements (Nocquet et al., 2012).

The morphology of the margin shows two distinct domains separated by a SW-NE trending ridge called the Imperia promontory (Soulet et al., 2016, their Fig. 1). The western sector presents seventeen submarine canyons perpendicular to the coastline with steep gradients (up to $10^{\circ}$ ) and numerous remarkable mass transport deposits (MTD) and largescale failure scars affecting the base of the continental slope (Migeon et al., 2011). South of the Imperia promontory, a recent morpho- and seismo-tectonic analysis highlighted a set of $\mathrm{N} 60-70^{\circ} \mathrm{E}$ steep slopes at the foot of the margin representing a fault system in relation with local seismicity (Larroque et al., 2011). The central and eastern sector presents larger, deeply incised submarine canyons (the Finale, Polcevera, Bisagno and Levante canyons; Soulet et al., 2016, their Fig. 1). These canyons are separated by wide interfluve areas on the continental slope and merge downslope into the Genova submarine valley (Soulet et al., 2016, their Fig. 6).

The morphology of the Ligurian margin first impacted by the LIW (Figs. 1, 2), mostly the Levante Riviera from Portofino to Genova, is rather abrupt (with bathymetric gradients locally up to $15^{\circ}$ ) and dominated by the presence of deeply incised canyons, including, from $E$ to $W$, the Levante, the Bisagno and the Polcevera canyons (Migeon et al., 2011; Fig. 3). In absence of multibeam bathymetry and with only scattered sparker data, the eastern Riviera sector was initially interpreted as dominated by gravity-driven mass wasting and erosional 
sedimentary processes (Corradi et al., 2001; Fig. 4A). The identified contourites in this area are located at about 200-1000 m w.d., mainly under the influence of the LIW as part of the Northern Current (Fig. 3; Soulet et al., 2016, their Fig. 6).

\section{MATERIALS AND METHODS}

\subsection{Circulation model}

In order to highlight water mass circulation close to the seafloor along the Ligurian margin, we used the coastal and regional circulation model MARS3D (3D hydrodynamical Model for Applications at Regional Scale) of Ifremer, developed by Lazure and Dumas (2008). The MENOR (NW Mediterranean) configuration of the MARS3D model extends from the Balearic Islands to the Gulf of Lions and the Ligurian Sea (longitude: $0^{\circ} \mathrm{E} 16^{\circ} \mathrm{E}$, latitude: $39.5^{\circ} \mathrm{N}$ $44.5^{\circ} \mathrm{N}$ ). It has a horizontal resolution of $1.2 \mathrm{~km}$ and 60 levels using generalised sigma coordinates system, refined near the surface and the bottom boundary layer. The open boundaries and initial conditions were obtained from a coarser global circulation model (PSY2V4/Mercator Ocean) which assimilates SLA (Sea Level Anomaly), SST (Sea Surface Temperature) and T-S (temperature, salinity) profiles. The atmospheric forcing is provided by the ARPEGE-HR model from Météo-France. The time window of choice for the simulation was winter 2013 (January to March) as representative of particularly energetic conditions, and summer 2013 (July to September) as a period of weak currents.

\subsection{Bathymetric, seismic reflection and sediment core data}

The large scale bathymetric data for Figure 1 map come from the GEBCO dataset (GEBCO_08, version 2010-09-27, http://www.gebco.net) with a 30 arc-second resolution. The multibeam bathymetry of the Ligurian Sea was acquired with a Simrad EM300 system onboard R/V Le Suroit during campaigns MALISAR1, MALISAR2, MALISAR3 (2006, 2007, 2008, respectively), processed and merged with the Ifremer Caraïbes software in a DTM with grid resolution of $50 \mathrm{~m}$.

Sub-Bottom Profiler (SBP) data, with sub-metric resolution and penetration in the order of $60 \mathrm{~ms}$ in the study area, were acquired using a hull mounted systems with a $1800-5300 \mathrm{~Hz}$ source during the PRISME3 cruise onboard R/V Pourquoi pas? and processed with the QC SUBOP software developed by Ifremer. The deep-towed SYSIF SBP, with a $220-1050 \mathrm{~Hz}$ source (Ker et al., 2010), was towed at 2 knot speed $100 \mathrm{~m}$ above the seafloor during the PRISME2 cruise onboard R/V L'Atalante. It provides in the study area profiles with metric resolution and penetration up to $200 \mathrm{~ms}$.

Calypso piston core PSM3-CS023 was collected with the R/V Pourquoi pas? during the PRISME3 campaign, scanned with a Geotek ${ }^{\circledR}$ Multi-Sensor Core Logger for P-wave velocity 
and gamma-density measurements at 1-cm step, opened and described onboard. The Pwave velocity was also measured directly on the split core with a step of $15 \mathrm{~cm}$. Additional density measurements were obtained from the moisture content considering the density of water equal to $1 \mathrm{~g} \cdot \mathrm{cm}^{-3}$ and the density of the sediment solid fraction $2.66 \mathrm{~g} \cdot \mathrm{cm}^{-3}$.

\section{RESULTS}

\subsection{Circulation model results}

The results of the MARS3D MENOR model show a marked seasonal variability of oceanic circulation in the Ligurian Sea, with more intense circulation during winter, in coherence with field observations (Albérola et al., 1995). During winter 2013, two main zones of fast bottom currents can be identified along the Ligurian margin: one at 100-200 m water depth and another at 400-1000 m water depth (Fig. 2A). The upper zone presents mean velocities ranging between 13 and $20 \mathrm{~cm} \cdot \mathrm{s}^{-1}$, while bottom currents are slightly slower in the deeper zone and comprised between 12 and $17 \mathrm{~cm} \cdot \mathrm{s}^{-1}$ (Fig. 2A). In contrast, during summer 2013 bottom currents are much weaker in the upper zone (100-200 m w.d.) with velocities of 4-8 $\mathrm{cm} \cdot \mathrm{s}^{-1}$ (Fig. 2C). In the deeper zone (400-1000 m w.d.), mean velocities are comprised between 8 and $12 \mathrm{~cm} \cdot \mathrm{s}^{-1}$ (light blue in Fig. 2C). This currents are part of the Northern Current that is a branch of the general North-Western Mediterranean cyclonic circulation (Pinardi et al., 2015).

The model results show a peak in salinity near the seafloor at 200-1000 m w.d. that corresponds with the Levantine Intermediate Water (LIW; Fig. 2B). The salinity near the seafloor along the Ligurian margin is higher in winter due to a higher transport of LIW from the Corsica trough towards the Ligurian Sea (Fig. 2B). In summer this transport across the Corsica trough is reduced and the salinity of the LIW along the Ligurian margin is closer to the salinity of the LIW along the western margin of Corsica (Fig. 2D). The "bottom current flow' of LIW hits the Ligurian margin north of the Corsica trough and then veers towards the NW, parallel to the coastline (Fig. 2). This current is obviously unstable and characterised by frequent eddies forced to follow the isobaths. Figures 2 and 3 show in particular that the faster flow of LIW has a maximum also at 400-800 m water depth.

\subsection{Comparison of seafloor morphology and circulation model results}

The analysis of multibeam bathymetry along the Ligurian margin reveals the presence of mounded morphologies in interfluve areas comprised within limited water depth ranges and parallel to the direction of LIW flow. By coupling the results of the circulation model with the seafloor geomorphology, we observe that mounded morphologies compatible with the interpretation of contourite drifts are present in two bathymetric zones: a) in zones of lower 
bottom current velocities located at 200-600 m w.d. between two veins of fast currents, and b) below the deep vein at about $900 \mathrm{~m}$ w.d. (Fig. 3).

The morphologies between 200 and $600 \mathrm{~m}$ in canyon interfluve areas are located between two LIW veins. Two bathymetric profiles show convex morphologies interpreted as possible plastered drifts (Fig. 3A, profiles 3C-2 and 3C-3) due to their convex shape (Fig. 3) and seismic echofacies (Soulet et al., 2016).

Offshore Portofino, between the Levante and the Bisagno canyons, a submarine terrace developed between 400 and $800 \mathrm{~m}$ w.d. (Fig. 3B, profile 3C-1) in a zone affected by relatively fast bottom currents (mean current velocities of $12-17 \mathrm{~cm} \cdot \mathrm{s}^{-1}$ during winter 2013; Figs. 2, 3). This terrace is likely sculpted by the action of the Northern Current. The effects of these strong bottom currents can be also observed in the deformation of the pockmarks that have an elongated shape in the direction of the currents and a destroyed flank downstream (Fig. 3B).

At around 900-1000 m w.d., at the interface between the LIW and the WMDW in a zone of minimum current velocity (Fig. 5), the Portofino drift appears separated from the slope by a 60-m deep moat (Figs. 3, 4). This drift can thus be interpreted as a separated mounded drift (Figs. 4, 5). The Portofino separated mounded drift is located immediately seawards of a band of high velocity bottom current, where current velocity drops allowing sediment accumulation (Figs. 3B, 4B, 5A).

A detailed analysis of seafloor morphology coupled with the results of the circulation model is effective to enhance the identification of drift deposits and erosional features linked to the action of bottom currents. The seismic profile of Figure $4 \mathrm{~B}$ has the same horizontal extent of the two radial profiles of oceanographic parameters from MARS3D (Fig. 5A, B). By comparing them it is possible to appreciate the fact that the water depth range where the Portofino drift is present (sediment drift formation zone, Fig. 5A) coincides with the lowest values of bottom current velocity, immediately below the base of the LIW (Fig. 5B). On the contrary, the water depth ranges of higher bottom current velocity correspond either to the presence of a moat or of non deposition/erosion.

\subsection{Internal geometry and sedimentary facies of the Portofino drift}

The internal geometry of mounded morphologies was unclear in sparker lines and induced to interpretation of the whole thickness of up to $0.5 \mathrm{~s}$ TWTT as a landslide deposit or MTD (Corradi et al., 2001; Fig. 4A). A comparison with higher resolution SYSIF profile suggests, however, that some of the internal geometric patterns visible in the mounded morphologies are diagnostic of contourite drifts, in particular the presence of convergent reflections, of cyclic stacks of high amplitude reflections and the presence of truncated reflections along buried erosional surfaces (Fig. 4B). The Portofino separated mounded drift has a thickness 
of at least $150 \mathrm{~m}$. Additional SBP profiles confirm the presence of other diagnostic morphologies such as moats, and allow the identification of a separated mounded drift, with morphologies and internal geometries comparable with the relatively nearby Pianosa contourites (Miramontes et al., 2016a,b).

Mass transport deposits, identified by their acoustically transparent echofacies, are present but not pervasive as previously thought. MTDs appear stacked, of limited extent and with a maximum thickness of about $30 \mathrm{~ms}(22.5 \mathrm{~m}$ by assuming a sound velocity of 1500 $\mathrm{m} \cdot \mathrm{s}^{-1}$ ). Sediment core PSM3-CS023 recovered $22.2 \mathrm{~m}$ of sediment in the southern part of the Portofino drift, in $827 \mathrm{~m}$ water depth $\left(44^{\circ} 12,059^{\prime}\right.$ lat $\mathrm{N} ; 009^{\circ} 10,570^{\prime}$ lon $\left.\mathrm{E}\right)$. The lithology is overall mud dominated with presence of intervals ( 3 to 8 and 12 to $16 \mathrm{mbsf}$ ) where $\mathrm{mm}$ - to $\mathrm{cm}$-thick silt to fine sand beds with bioturbation are present (Fig. 6A). This facies association, highlighted also by the pattern of gamma density and P-wave velocity curves, is in part comparable to that of core PSM3-CS009 recovered from a contourite drift of the Pianosa contourite depositional system (Miramontes et al., 2016a), where two clusters of thin silt to fine sand laminae are identified at 0-2 and 12-16 mbsf and correspond to higher amplitude seismic reflections (Fig. 6B, 6D). The comparison supports the identification of the Portofino drift as a contourite deposit. However, there is a peculiarity present in core PSM3-CS023 where, at 13 to $14 \mathrm{mbsf}$ some tilted layers suggest the presence of a MTD corresponding to a seismically transparent unit (Fig. 6C).

\section{DISCUSSION}

\subsection{The Portofino contourite drift VS submarine landslide}

The analysis of the whole MALISAR dataset suggests that echofacies compatible with contourite drift accumulation are widespread within well identified water depth ranges in most of the interfluves among Ligurian canyons, at least in the Eastern Riviera (Soulet et al., 2016). The Portofino separated drift has a well identified diagnostic internal geometry. However, the sedimentary deposits upslope the Portofino drift present an articulated internal architecture where seismic units with transparent echofacies are stacked and interfingered among packages of continuous reflections.

The presence of acoustically transparent units likely suggested a former interpretation of the mounded feature as the accumulation of a submarine landslide (Corradi et al., 2001). Sediment instability recorded in the form of meter-thick MTD within the drift could testify local slope failures originated upslope the drift, in an area where erosion by LIW dominates and could act as a triggering factor for sliding, together with the high bathymetric gradients. A comparable process has been proposed for local mass wasting processes affecting the Pianosa contourite depositional system, an area where seismic activity is virtually absent 
(Miramontes et al., 2016b). In the case of the Portofino drift, local destabilization by earthquake activity cannot be excluded, even if seismicity is moderate (Larroque et al., 2012). Furthermore, the presence of several slide scars, for example limiting the submarine terrace of Figure 3B, could be seen as an example of interaction of metastable drift sediment, high morphologic gradients, localized erosion and sediment destabilization.

The Portofino drift is associated with erosion features (a marine terrace, elongated pockmarks, Fig. 3B) and mass wasting (landslide scarps at the edge of marine terrace, Fig. 3B, and MTDs, Figs.4A, 4B, 6). This complex association of sediment accumulation, erosion and mass wasting has been observed elsewhere (e.g., offshore Uruguay, Hernández Molina et al., 2016): the balance of sediment construction and destruction seems a parameter reflecting local geological conditions

\subsection{Contourite identification and current circulation models}

The identification of contourite deposits is based mainly on a combination of seafloor morphology features and diagnostic internal geometry in seismic reflection profiles. When available, sediment cores may support the identification of contourites. Each of these approaches alone may be non conclusive. The most widespread criterion of contourite identification is probably the morphology coupled with the internal geometry with converging reflections. The main disadvantage in using seismic reflection profiles to unequivocally identify contourites is the resolution of the seismic deployed. We emphasize the effectiveness of very high resolution tools such as deep-towed SYSIF as key to interpret the internal geometry of these sediment bodies, when possible.

An emerging criterion to identify contourites is the coupling of seafloor morphology and bottom water hydrodynamics. We are aware that contourite drifts form over much longer time spans than those possibly simulated by a circulation model limited in calculation time and based on boundary conditions that might be valid today but not in remote past conditions. The extrapolation of present oceanographic condition to the past, even if carefully calibrated with selected seasonality to reconstruct more extreme conditions, is not trivial and has to rely on reasonable assumptions. For example, the whole Plio-Quaternary record in the Pianosa contourite depositional system seems to have maintained a relatively constant setting for bottom currents, as testified by entertained morphologies and comparable paleogeography over the whole Plio-Quaternary (Miramontes et al., 2016a). This is not the case of contourite drifts originated occasionally in a continental margin and then buried by apparently 'noncurrent-dominated' deposits, as suggested by Dalla Valle et al. (2013) in the central Adriatic Sea: in these cases, independent support for contrasting bottom current regimes has to be searched and an actualistic approach cannot be applied. 
The main point of interest of a potentially diagnostic criterion for identifying past sedimentary processes (in this case the coupling of seafloor morphology/stratigraphy and hydrodynamic conditions) is its ability to make predictions. Based on the overall pattern of LIW circulation around Italy, we infer that several other focused spots for the accumulation of sediment drifts might exist, especially along the Tyrrhenian Sea sides (Fig. 1). The likeliness that contourite drifts grow in the proximity of promontories and seafloor irregularities has recently been proposed with an example from the southern Tyrrhenian Sea (Falcini et al., 2016).

\subsection{Implication in the correct identification of contourites along the Italian margins}

The importance of a correct identification of bottom current dominated deposits has several implications, linked in general to enhanced comprehension of the seafloor environment and to the peculiar pattern of sediment transport, accumulation and erosion. Sites of preferential sediment accumulation (e.g., contourite drifts), represent expanded stratigraphic sections that could be exploited for paleoenvironmental and paleoceanographic studies in areas formerly overlooked for lack of identified suitable targets (long and/or expanded sedimentary records). Along the Ligurian margin, for example, paleoclimate reconstruction series are scarce to absent with the exception of recent records of the past two millennia (Kaiser et al., 2014). Contourite drifts could constitute suitable sedimentary records for longer/more expanded paleoclimate reconstructions.

On the other hand, contourite deposits are heterogeneous in lithology and associated to short scale variations in pattern of erosion and deposition: this articulation could result in accumulation of sediment prone to failure, with implications in geohazard assessment. The erosion generated by intense bottom currents could act as an effective trigger of seafloor instability (Miramontes, 2016).

Finally, recent studies on marine biodiversity emphasize the importance of correctly appreciating the role of bottom current in shaping the benthic community both at the megamacrofaunal scale (e.g. deep water corals with asymmetrical distribution in the Adriatic Sea according to bottom current arrangement; Taviani et al., 2016), and at the meiofaunal scale, with remarkable difference in benthic assemblage diversity and abundance on lee- and stoss-sides of bedforms and drifts (Zeppilli et al., 2016).

\section{CONCLUSIONS}

A brief review of the published evidence of contourite deposits in the seas around Italy shows two main features: 1) focused bottom current morphologies linked to areas of deep water formation in the Adriatic Sea, and 2) a series of contourite drifts aligned roughly along 
the path of the Levantine Intermediate Waters circulating from East to West from the Adriatic to the Ionian and Tyrrhenian Seas.

By applying the MARS3D hydrodynamic model in an area including the Corsica trough and the Ligurian margin, we show that during winter 2013 (a period possibly representative of extreme conditions) a branch of LIW reached the Ligurian margins with a mean velocity exceeding $20 \mathrm{~cm} \cdot \mathrm{s}^{-1}$ and bottom shear stress $>0.2 \mathrm{~N} \cdot \mathrm{m}^{-2}$, in water depth of 400 to $800 \mathrm{~m}$. The analysis of bottom currents and the use of modelling tools thus helped identify areas of potential contouritic deposits.

A mounded deposit offshore Portofino in about $1000 \mathrm{~m}$ water depth formerly interpreted as the accumulation of a large submarine landslide, after analysis with higher resolution deep-towed geophysical tools, has proved to be overall a complex contourite deposit: it includes plastered drifts and a separated mounded drift containing meter-thick intervals of acoustically transparent seismic units that correspond to sedimentary successions with tilted layers. These layers could represent the deposit of episodic small-volume mass wasting possibly caused by steep seafloor gradients and/or erosion by bottom currents.

The Portofino drift occurs in an area where Levantine Intermediate Waters hits the Ligurian margin along the well identified northward trajectory of LIW. The drift appears located at $900-1000 \mathrm{~m}$ water depth and is at least $150 \mathrm{~m}$ thick. The Portofino drift is likely the expression of prolonged current actions able to accumulate sediment in sheltered sites and erode where shear stress exerted at the seafloor is stronger. The action of bottom current erosion in areas upslope of the separated Portofino drift caused a series of erosiondominated morphologies, including elongated pockmarcks and a flat marine terrace.

Other areas with contourite drifts could exist westwards in other sectors of the Ligurian margin as suggested in Soulet et al. (2016) and in several other sectors of the Tyrrhenian Sea. We predict that several drifts are yet to be discovered, especially in sites along the LIW path where the interaction of current and morphology is somehow forced (straits, islands, and promontories). Implications in the correct identification of bottom-current related features (areas of sediment accumulation, erosion and failure) include chances of better assessing paleoenvironmental and paleoclimatic reconstructions, geohazards, and biodiversity issues.

\section{ACKNOWLEDGEMENTS}

We thank captain and crew of campaigns MALISAR1, MALISAR2 and MALISAR3 (R/V Le Suroit: 2006-2009, doi10.18142/207), PRISME2 (R/V L'Atalante, 2013, doi10.17600/13010050), PRISME3 (R/V Pourquoi pas?, 2013, doi 10.17600/13030060). We acknowledge CINES for BULL Occigen computer access (project ode7663). EM PhD was co-funded by Ifremer and TOTAL within the scientific project PAMELA (Passive Margins Exploration Laboratories). We thank P. de Clarens and other colleagues implied in the 
PAMELA project for enriching discussions. Insightful comments by reviewers E. Martorelli and D. Casalbore, together with the suggestions and support of guest editor S. Longhitano substantially improved the manuscript. This is CNR-ISMAR contribution n 1920.

\section{REFERENCES}

Albérola, C., Millot, C., Font, J., 1995. On the seasonal and mesoscale variabilities of the Northern Current during the PRIMO-0 experiment in the Western Mediterranean Sea. Oceanologica Acta 18,163-192.

Amelio, M., Martorelli, E., 2008. Seismo-stratigraphic characters of paleocontourites along the Calabro- Tyrrhenian margin (Southern Tyrrhenian Sea). Mar. Geol. 252, 141-149.

Artale, M., Gasparini, G.P., 1990. Simultaneous temperature and velocity measurements of the internal wave field in the Corsican Channel (Eastern Ligurian Sea). Journal of Geophysical Research 95(C2), 1635-1645.

Berndt, C., Cattaneo, A., Szuman, M., Trincardi, F., Masson, D., 2006. Sedimentary structures offshore Ortona, Adriatic Sea - Deformation or sediment waves? Marine Geology 234, 261-270.

Canals, M., Puig, P., Durrieu de Madron, X., Heussner, S., Palanques, A., Fabrés, J., 2006. Flushing submarine canyons. Nature 444, 354-357.

Cattaneo, A., Trincardi, F., Langone, L., Asioli, A., Puig, P., 2004. Clinoform Generation on Mediterranean Margins. Oceanography, 17/4, 104-117. doi.org/10.5670/oceanog.2004.08

Cattaneo, A., Trincardi, F., Asioli, A., Correggiari, A., 2007. The Western Adriatic Shelf Clinoform: Energy-limited bottomset. Continental Shelf Research 27, 506-525.

Cattaneo, A., Jouet, G., Charrier, S., Théreau, E., Riboulot, V., 2014. Submarine Landslides and Contourite Drifts Along the Pianosa Ridge (Corsica Trough, Mediterranean Sea). In: S. Krastel et al. (Eds.), Submarine Mass Movements and Their Consequences, Advances in Natural and Technological Hazards Research 37, Springer, 435-445, DOI 10.1007/978-3-319-00972-8_39.

Chiggiato, J., Schroeder, K., Trincardi, F., 2016. Cascading dense shelf-water during the extremely coldwinter of 2012 in the Adriatic, Mediterranean Sea: Formation, flow, and seafloor impact .Marine Geology 375, 1-4.

Corradi, N., Cuppari, A., Fanucci, F., Morelli, D., 2001. Gravitative instability of sedimentary masses on the Ligurian Sea margins. GeoActa.1, 37-44.

Dalla Valle, G., Gamberi, F., Rocchini, P., Minisini, D., Errera, A., Baglioni, L., Trincardi, F.,, 2013. 3D seismic geomorphology of mass transport complexes in a foredeep basin: Examples from the Pleistocene of the Central Adriatic Basin (Mediterranean Sea). Sedimentary Geology 294, 127-141.

Durrieu de Madron, X., Houpert, L., Puig, P., Sanchez-Vidal, A., Testor, P., Bosse, A., Estournel, C., Somot, S., Bourrin, F., Bouin, M.N., Beauverger, M., Beguery, L., Calafat, A., Canals, M., Cassou, C., Coppola, L., Dausse, D., D’Ortenzio, F., Font, J., Heussner, S., Kunesch, S., Lefevre, D., Le Goff, H., Martín, J., Mortier, L., Palanques, A., Raimbault, P., 2013. Interaction of dense shelf water cascading and open-sea convection in the northwestern Mediterranean during winter 2012. Geophysical Research Letters 40, 1379-1385. 
Ercilla, G., Juan, C., Hernández-Molina, F.J., Bruno, M., Estrada, F., Alonso, B., Casas, D., Farran, M.I., Llave, E., García, M., Vázquez, J.T., D'Acremont, E., Gorini, C., Palomino, D., Valencia, J., EI Moumni, B., Ammar, A., 2016. Significance of bottom currents in deep-sea morphodynamics: An example from the Alboran Sea. Mar. Geol. 378, 157-170.

Falcini, F., Martorelli, E., Chiocci, F.L., Salusti, E., 2016. A general theory for the effect of local topographic unevenness on contourite deposition around marine capes: An inverse problem applied to the Italian continental margin (Cape Suvero). Marine Geology 378, 74-80.

Foglini, F., Campiani, E., Trincardi, F., 2016. The reshaping of the SouthWest Adriatic Margin by cascading of dense shelf waters. Marine Geology 375, 64-81.

Gamberi, F., Marani, M., 2006. Hinterland geology and continental margin growth: the case of the Gioia Basin (southeastern rjr). Geol. Soc. Lond., Spec. Publ. 262 (1), 349-363.

Hernández-Molina, F.J., Soto, M., Piola, A.R., Tomasini, J., Preu, B., Thompson, P., Badalini, G., Creaser, A., Violante, R.A., Morales, E., Paterlini, M., De Santa Ana, H., 2016. A contourite depositional system along the Uruguayan continental margin: Sedimentary, oceanographic and paleoceanographic implications. Mar. Geol. 378, 333-349.

Jolivet, L., Faccenna, C., 2000. Mediterranean extension and the Africa-Eurasia collision. Tectonics 19, 1095-1106.

Kaiser, J., Ruggieri, N., Hefter, J., Siegel, H., Mollenhauer, G., Arz, H.W. Lamy, F., 2014. Lipid biomarkers in surface sediments from the Gulf of Genoa, Ligurian sea (NW Mediterranean sea) and their potential for the reconstruction of palaeo-environments. Deep Sea Research I 89, 68-83. doi:10.1016/j.dsr.2014.04.009

Ker, S., Marsset, B., Garziglia, S., Le Gonidec, Y., Gibert, D., Voisset, M., Adamy, J., 2010. Highresolution seismic imaging in deep sea from a joint deep-towed/OBH reflection experiment : application to a Mass Transport Complex offshore Nigeria. Geophys. J. Int. 182, 1524-1542.

Larroque, C., Mercier de Lépinay, B., Migeon, S., 2011. Morphotectonic and fault-earthquake relationships along the northern Ligurian margin (Western Mediterranean) based on high resolution multibeam bathymetry and multichannel seismic-reflection profiles. Marine Geophysical Researches, 32, 163-179, doi:10.1007/s11001-010-9108-7.

Larroque, C., Scotti, O., loualalen, M., 2012. Reappraisal of the 1887 Ligurian earthquake (western Mediterranean) from macroseismicity, active tectonics and tsunami modelling. Geophys. J. Int. 190, 87-104. doi: 10.1111/j.1365-246X.2012.05498.

Lascaratos, A., Roether, W., Nittis, K., Klein, B.,1999. Recent changes in deep water formation and spreading in the eastern Mediterranean Sea: a review. Progress in Oceanography 44, 5-36.

Lazure, P., Dumas F., 2008. An external-internal mode coupling for a 3D hydrodynamical model for applications at regional scale (MARS), Advances in Water Resources, 31, 233-250.

Marani, M., Argnani, A., Roveri, M., Trincardi, F., 1993. Sediment drifts and erosional surfaces in the central Mediterranean: seismic evidence of bottom-current activity. Sedimentary Geology 82, 207220.

Marini, M., Maselli, V., Campanelli, A., Foglini, F., Grilli, F., 2016. Role of the Mid-Adriatic deep in dense water interception and modification. Marine Geology 375, 5-14. 
Martorelli, E., Falcini, F., Salusti, E., Chiocci, F.L., 2010. Analysis and modelling of contourite drifts and currents off promontories in Southern Italian Seas (Mediterranean Sea). Mar. Geol. 278, 1930.

Martorelli, E., Petroni, G., Chiocci, F.L., the Pantelleria Scientific Party, 2011. Contourites offshore Pantelleria Island (Sicily Channel, Mediterranean Sea): depositional, erosional and biogenic elements. Geo-Mar. Lett. 31, 481-493.

Martorelli, E., Bosman, A.,.Casalbore, D., Falcini, F., 2016. Interaction of down-slope and along-slope processes off Capo Vaticano (southern Tyrrhenian Sea, Italy), with particular reference to contourite related landslides. Marine Geology 378, 43-55.

Micallef, A., Foglini, F., Le Bas, T., Angeletti, L., Maselli, V., Pasuto, A., Taviani, M., 2013. The submerged paleolandscape of the Maltese Islands: Morphology, evolution and relation to Quaternary environmental change. Marine Geology 335, 129-147.

Migeon, S., Cattaneo, A., Hassoun, V., Larroque, C., Corradi, N., Fanucci, F., Dano, A., Mercier de Lepinay, B., Sage, F., Gorini, C.., 2011. Morphology, distribution and origin of recent submarine landslides of the Ligurian Margin (North-western Mediterranean): some insights into geohazard assessment. Marine Geophysical Research 32, 225-243. DOI:10.1007/s11001-011-9123-3

Milligan, T.G., Cattaneo, A., 2007. Sediment Dynamics in the Western Adriatic Sea: From transport to stratigraphy. Continental Shelf Research 27, 287-295.

Millot, C., 2009. Another description of the Mediterranean Sea outflow. Progress in Oceanography 82, 101-124.

Millot, C., Taupier-Letage I., 2005. Circulation in the Mediterranean Sea. In: Saliot A, editor, The Mediterranean Sea, Handbook of Environmental Chemistry. Berlin Heidelberg: Springer, Vol. 5: Water Pollution, Part K, pp. 29-66. DOI:10.1007/s11001-011-9123-3

Miramontes, E., 2016. Glissements sous-marins en Mer Tyrrhénienne septentrionale et relations avec les dépôts contouritiques et turbiditiques : morphologie, stratigraphie, géotechnique et modélisation. PhD thesis, Université de Bretagne Occidentale, $215 \mathrm{pp}$.

Miramontes, E., Cattaneo, A., Jouet, G., Théreau, E., Thomas, Y., Rovere, M.,. Cauquil, E. Trincardi, F., 2016a. The Pianosa Contourite Depositional System (Corsica Trough, Northern Tyrrhenian Sea): drift morphology and Plio-Quaternary stratigraphic evolution. Marine Geology 378, 20-42. doi:10.1016/j.margeo.2015.11.004

Miramontes, E., Cattaneo, A., Jouet, G., Garziglia, S., 2016b. Implications of Sediment Dynamics in Mass Transport along the Pianosa Ridge (Northern Tyrrhenian Sea). In Lamarche, J. et al. (Eds). Submarine Mass Mouvements and Their Consequences 7th international symposium. Springer. Advances in Natural and Technological Hazards Research 41, 301-309.

Pellegrini, C., Maselli, V., Trincardi, F., 2015. Pliocene-Quaternary contourite depositional system along the south-western Adriatic margin: changes in sedimentary stacking pattern and associated bottom currents. Geo-Mar Lett DOI 10.1007/s00367-015-0424-4

Pinardi, N., Zavatarelli, M., Adani, M., Coppini, G., Fratianni, C., Oddo, P., Simoncelli, S., Tonani, M., Lyubarstsev, V., Dobrici, S., Bonaduce, A. (2015). Mediterranean Sea large-scale low-frequency 
ocean variability and water mass formation rates from 1987 to 2007: A retrospective analysis. Progress in Oceanography, 132, 318-332.

Rebesco, M., Hernández-Molina, F.J., Van Rooij, D., Wåhlin, A., 2014. Contourites and associated sediments controlled by deep-water circulation processes: state of the art and future considerations. Mar. Geol. 352, 111-154.

Reeded M.S., Rothwell, G., Stow, D.A.V., 2002. The Sicilian gateway: anatomy of the deep-water connection between East and West Mediterranean basins. Geological Society, London, Memoirs 22, 171-189. doi: 10.1144/GSL.MEM.2002.022.01.13

Rollet, N., Déverchère, J., Beslier, M.O., Guennoc, P., Réhault, J.P., Sosson, M., Truffert, C.,2002. Back arc extension, tectonic inheritance and volcanism in the Ligurian Sea, Western Mediterranean. Tectonics 21, doi:10.1029/2001TC900027.

Roveri, M., 2002. Sediment drift of the Corsica Channel, northern Tyrrhenian Sea. In: Stow D.A.V., Pudsey C.J., Howe J.A., Faugères J.-C., Viana A. (Eds). Deep-water contourite systems: modern drifts and ancient series, seismic and sedimentary characteristics, Geological Society of London Memoirs, 22, pp 191- 208.

Savini, A., Corselli, C., 2010. High-resolution bathymetry and acoustic geophysical data from Santa Maria di Leuca Cold Water Coral province (Northern Ionian Sea-Apulian continental slope). DeepSea Research II 57, 326-344.

Schaaff, E., Grenz, C., Pinazo, C., 2002. Erosion of particulate inorganic and organic matter in the Gulf of Lion. Comptes Rendus Geoscience 334 (15), 1071-1077.

Soulet, Q., Migeon,;S., Gorini, C.,; Rubino;J.-L., Raisson;F., Bourges.P. Erosional versus aggradational canyons along a tectonically-active margin: the Northeastern Ligurian Margin (Western Mediterranean Sea). Marine Geology, 382, 17-36.

Soulsby, R.L., 1997. Dynamics of marine sands. A manual for practical applications. Thomas Telford, London, pp. 249.

Stow, D.A.V., Kahler, G., Reeder, M., 2002. Fossil contourites: type example from an Oligocene palaeoslope system, Cyprus. In: Stow, D.A.V., Pudsey, C.J., Howe, J.A., Faugères, J.-C., Viana, A.R. (Eds.), Deep-water Contourite Systems: Modern Drifts and Ancient Series, Seismic and Sedimentary Characteristics. Geological Society, London, Memoir, 22, pp. 443-455.

Taviani, M., Remia, A., Corselli, C., Freiwald, A., Malinverno, E., Mastrototaro, F., Savini, A.,Tursi, A., 2005.First geo-marine survey of living cold-water Lophelia reefs in the Ionian Sea (Mediterranean Basin). Facies 50, 409-417.

Taviani, M., Angeletti, L., Beuck, L., Campiani, E., Canese, S., Foglini, F., Freiwald, A., Montagna, P., Trincardi, F., 2016. Reprint of 'On and off the beaten track: Megafaunal sessile life and Adriatic cascading processes'. Marine Geology 375, 146-160.

Trincardi, F., Verdicchio, G., Miserocchi, S., 2007. Sea-floor evidence for the interaction between Cascading and along-slope bottom-water masses. J. Geophys. Res. 112, F03011. doi.org/10.1029/2006JF000620. 
Tripsanas, E.K., Panagiotopoulos, I.P., Lykousis, V., Morfis, I., Karageorgis, A.P., Anastasakis, G., Kontogonis, G., 2016. Late quaternary bottom-current activity in the south Aegean Sea reflecting climate-driven dense-water production. Mar. Geol. 375, 99-119.

Urgeles, R, Cattaneo, A, Puig, P, Liquete, C, De Mol, B, Amblàs, D, Sultan, N, Trincardi, F., 2011. A review of undulated sediment features on Mediterranean prodeltas: distinguishing sediment transport structures from sediment deformation. Marine Geophysical Research 32, 49-69. DOI: 10.1007/s11001-011-9125-1

Verdicchio, G., Trincardi, F. 2006. Short-distance variability in abyssal bed-forms along the Southwestern Adriatic Margin (Central Mediterranean). Marine Geology 234, 271-292.

Verdicchio, G, Trincardi F., 2008a. Shallow water contourites. In: Rebesco M, Camerlenghi A (eds) Contourites, Developments in sedimentology, Elsevier, Amsterdam, 60, pp 409-433.

Verdicchio, G., Trincardi, F., 2008b. Mediterranean shelf-edge muddy contourites: examples from the Gela and South Adriatic basins. Geo-Mar. Lett. 28, 137-151.

Zeppilli, D., Pusceddu, A., Trincardi, F., Danovaro, R., 2016. Seafloor heterogeneity influences the biodiversity-ecosystem functioning relationships in the deep sea. Scientific Reports 6:26352 |DOI: 10.1038/srep26352

\section{TABLE AND FIGURE CAPTIONS}

Table 1. Occurrences of contourite deposits around Italy signaled in the literature. The type of contourite is attributed in the present study based on the classification of Rebesco et al. (2014). The water depth range comes from the comparison of published papers. * Present water depth, possibly deeper at the time of drift formation.

Figure 1. Bathymetric map of the seas around Italy with indication of the main bottom current path (based on Millot and Taupier-Letage, 2005) and of sites where contourite deposits were identified (see Tab. 1).

Figure 2. Results of MARS 3D / MENOR model output (3D hydrodynamical Model for Applications at Regional Scale, NW Mediterranean configuration; Lazure and Dumas, 2008) with cell size of $1.2 \mathrm{~km}$ showing the presence of LIW moving northwards from the Corsica trough towards the Ligurian margin and then westwards. A) and B) show respectively mean bottom current velocity and salinity at the seafloor during winter 2013 (January to March). C) and D) show the same parameters during summer 2013 (July to September).

Figure 3. A) Bathymetric map of the Ligurian margin (DTM grid resolution $50 \mathrm{~m}$ ) with location of bathymetric profiles 3C-2 and 3C-3 and with superposed vectors of mean bottom current velocity of MARS3D for winter 2013. B) Zoom of the bathymetry in the area offshore 
Portofino: the Portofino separated mounded drift is in an area of low velocity. Several erosional/deformation features are visible at the seafloor possibly associated with bottom current erosion: marine terrace, elongated pockmarks. See the location of seismic profiles of Fig. 4 and bathymetric profile 3C-1. C) Bathymetric profiles showing seafloor morphology in three sectors: $\mathrm{C}-1$ shows the presence of a flat marine terrace swept by strong bottom current; C-2 and C-3 show a water depth range with convex morphology corresponding likely to the presence of a plastered drift.

Figure 4. Seismic reflection profiles offshore Portofino: A) previously published Sparker profile with interpretation by Corradi et al. (2001), where a prominent sediment bulge here interpreted as the Portofino drift was considered as the accumulation of a submarine landslide above basal failure surfaces (dashed in white). B) Deep-towed SYSIF profile shot at the same location showing the detailed internal geometry of the deposit, interpreted here as a separated mounded drift. The upslope wavy morphology is likely a combination of limited mass transport deposits (acoustically transparent seismic facies), contourite deposits and erosional surfaces. C) and D) SBP profiles also show the internal geometry of the mounded deposit with diagnostic converging reflections of a contourite drifts in the area offshore Portofino with a different orientation with respect to Fig. 4A-4B.

Figure 5. Radial profile (transect) showing MARS 3D / MENOR model output of mean bottom current velocity (A) and salinity (B) in winter 2013. This profile coincides with the SYSIF seismic reflection profile of Fig. 4B (location of profile in Fig. 3B). Water masses are clearly identified, in particular the Levantine Intermediate Water comprised between 400 and $800 \mathrm{~m}$ water depth. Note also the indication of the value of the percentile 90 (P90) of bottom shear stress reaching a value of $0.2 \mathrm{~N} \cdot \mathrm{m}^{-2}$. The threshold value for erosion of unconsolidated mud ranges between 0.02 and $0.05 \mathrm{~N} \cdot \mathrm{m}^{-2}$ (Schaaff et al., 2002) and for fine sand it is $0.1 \mathrm{~N} \cdot \mathrm{m}^{-2}$ (according to Shields in Soulby, 1997).

Figure 6. A, C) Mud-dominated sedimentary succession of the contourite drift offshore Portofino (core PSM3-CS023) with two intervals of thin silt to fine sand beds within bioturbated mud and presence of tilted layers at 13-14 mbsf corresponding to a transparent seismic echofacies in SYSIF seismic profile. B, D) Sediment core PSM3-CS009 with comparable lithology from mounded drift offshore Pianosa projected on a SBP profile (modified from Miramontes et al., 2016a). Note the comparable overall pattern of grain size and gamma-ray density suggesting several superposed contourite sequences separated by high amplitude reflections. 
ACCEPTED MANUSCRIPT

\begin{tabular}{|c|c|c|c|c|c|}
\hline $\mathbf{n}$ & zone & location & contourite type & $\begin{array}{l}\text { w. d. } \\
\text { range }(m)\end{array}$ & references \\
\hline 1 & $\begin{array}{l}\text { Central Adriatic } \\
\text { Sea }\end{array}$ & $\begin{array}{l}\text { Mid-Adriatic } \\
\text { Deep }\end{array}$ & patch mounded drifts & $170-210$ & Marini et al. (2016) \\
\hline 2 & $\begin{array}{l}\text { Central Adriatic } \\
\text { Sea }\end{array}$ & Pescara Basin & buried mounded drifts & paleoslope & Dalla Valle et al. 2013) \\
\hline 3 & $\begin{array}{l}\text { Southern } \\
\text { Adriatic Sea }\end{array}$ & $\begin{array}{l}\text { Gargano } \\
\text { Promontory }\end{array}$ & $\begin{array}{l}\text { elongated separated } \\
\text { mounded drifts }\end{array}$ & $500-600$ & $\begin{array}{l}\text { Trincardi et al. (2007) } \\
\text { Martorelli et al. (2010) } \\
\text { Verdicchio and } \\
\text { Trincardi (2006, 2008a) }\end{array}$ \\
\hline 4 & $\begin{array}{l}\text { Southern } \\
\text { Adriatic Sea }\end{array}$ & $\begin{array}{l}\text { Dauno } \\
\text { seamount }\end{array}$ & $\begin{array}{l}\text { elongated separated } \\
\text { mounded drifts }\end{array}$ & $300-1100$ & $\begin{array}{l}\text { Verdicchio and } \\
\text { Trincardi (2006) } \\
\text { Pellegrini et al. (2015) } \\
\text { Foglini et al. (2016) }\end{array}$ \\
\hline 5 & $\begin{array}{l}\text { Northern } \\
\text { Ionian Sea }\end{array}$ & $\begin{array}{l}\text { Eastern Otranto } \\
\text { Channel }\end{array}$ & $\begin{array}{l}\text { elongated separated } \\
\text { mounded drift }\end{array}$ & 1250 & Marani et al. (1993) \\
\hline 6 & $\begin{array}{l}\text { Northern } \\
\text { Ionian Sea }\end{array}$ & Apulian margin & mounded drift & $650-850$ & $\begin{array}{l}\text { Taviani et al. (2005) } \\
\text { Savini and Corselli } \\
(2010)\end{array}$ \\
\hline 7 & $\begin{array}{l}\text { Western Ionian } \\
\text { Sea }\end{array}$ & Messina Rise & $\begin{array}{l}\text { dunes (large-scale } \\
\text { bedforms) }\end{array}$ & $2300-2500$ & Marani et al. (1993) \\
\hline 8 & Sicily Channel & NE Malta & $\begin{array}{l}\text { elongated separated } \\
\text { mounded drift }\end{array}$ & $125-145$ & Micallef et al. (2013) \\
\hline 9 & Sicily Channel & Gela Basin & mounded drifts & $170-300$ & $\begin{array}{l}\text { Verdicchio and } \\
\text { Trincardi (2008a) }\end{array}$ \\
\hline 10 & Sicily Channel & $\begin{array}{l}\text { Offshore } \\
\text { Pantelleria } \\
\text { Island }\end{array}$ & $\begin{array}{l}\text { elongated separated } \\
\text { mounded drift }\end{array}$ & $250-750$ & Martorelli et al. (2011) \\
\hline 11 & Sicily Channel & $\begin{array}{l}\text { Sicily Channel } \\
\text { Sill }\end{array}$ & confined drift & $950-1000$ & $\begin{array}{l}\text { Marani et al. (1993), } \\
\text { Reeder et al. (2002) }\end{array}$ \\
\hline 12 & $\begin{array}{l}\text { Southern } \\
\text { Tyrrhenian Sea }\end{array}$ & Cefalu Basin & $\begin{array}{l}\text { dunes (large-scale } \\
\text { bedforms) }\end{array}$ & $1000-1200$ & Marani et al. (1993) \\
\hline 13 & $\begin{array}{l}\text { Southern } \\
\text { Tyrrhenian Sea }\end{array}$ & $\begin{array}{l}\text { Cape Vaticano } \\
\text { (Gioia and Paola } \\
\text { Basins) }\end{array}$ & $\begin{array}{l}\text { elongated separated } \\
\text { mounded drift }\end{array}$ & $600-700$ & $\begin{array}{l}\text { Marani et al. (1993) } \\
\text { Gamberi and Marani } \\
(2006) \\
\text { Martorelli et al. (2010, } \\
2016)\end{array}$ \\
\hline 14 & $\begin{array}{l}\text { Southern } \\
\text { Tyrrhenian Sea }\end{array}$ & Capo Suvero & $\begin{array}{l}\text { buried elongated } \\
\text { separated mounded drifts }\end{array}$ & $110-240$ * & $\begin{array}{l}\text { Amelio and Martorelli } \\
(2008)\end{array}$ \\
\hline 15 & $\begin{array}{l}\text { Northern } \\
\text { Tyrrhenian Sea }\end{array}$ & Corsica Trough & $\begin{array}{l}\text { plastered drifts, } \\
\text { elongated separated } \\
\text { mounded drifts, } \\
\text { multicrested drifts, } \\
\text { sigmoid drifts }\end{array}$ & $170-850$ & $\begin{array}{l}\text { Marani et al. (1993) } \\
\text { Roveri (2002) } \\
\text { Cattaneo et al. (2014) } \\
\text { Miramontes et al. } \\
(2016 a, b)\end{array}$ \\
\hline 16 & Ligurian Sea & $\begin{array}{l}\text { Offshore } \\
\text { Portofino }\end{array}$ & $\begin{array}{l}\text { separated mounded drift, } \\
\text { plastered drift, terrace }\end{array}$ & $200-1000$ & $\begin{array}{l}\text { Soulet et al (2016); } \\
\text { This study }\end{array}$ \\
\hline
\end{tabular}

Tab. 1 


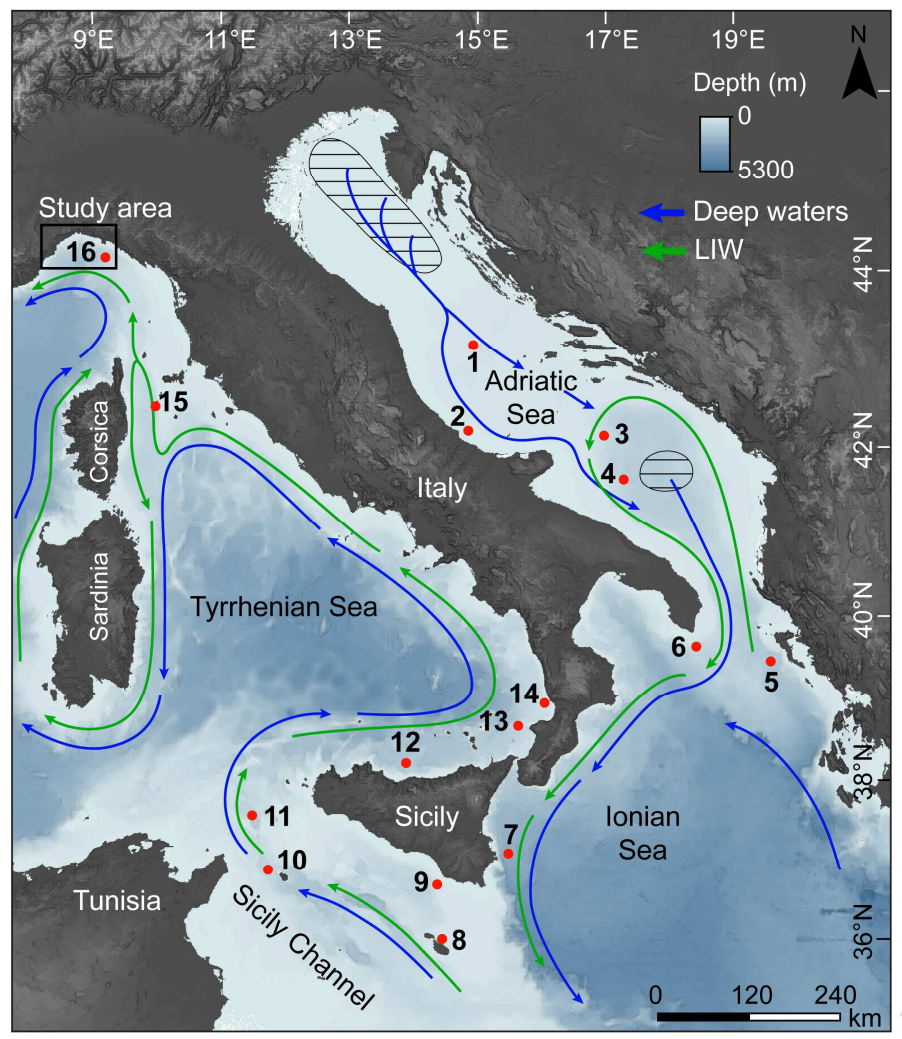




\section{ACCEPTED MANUSCRIPT}
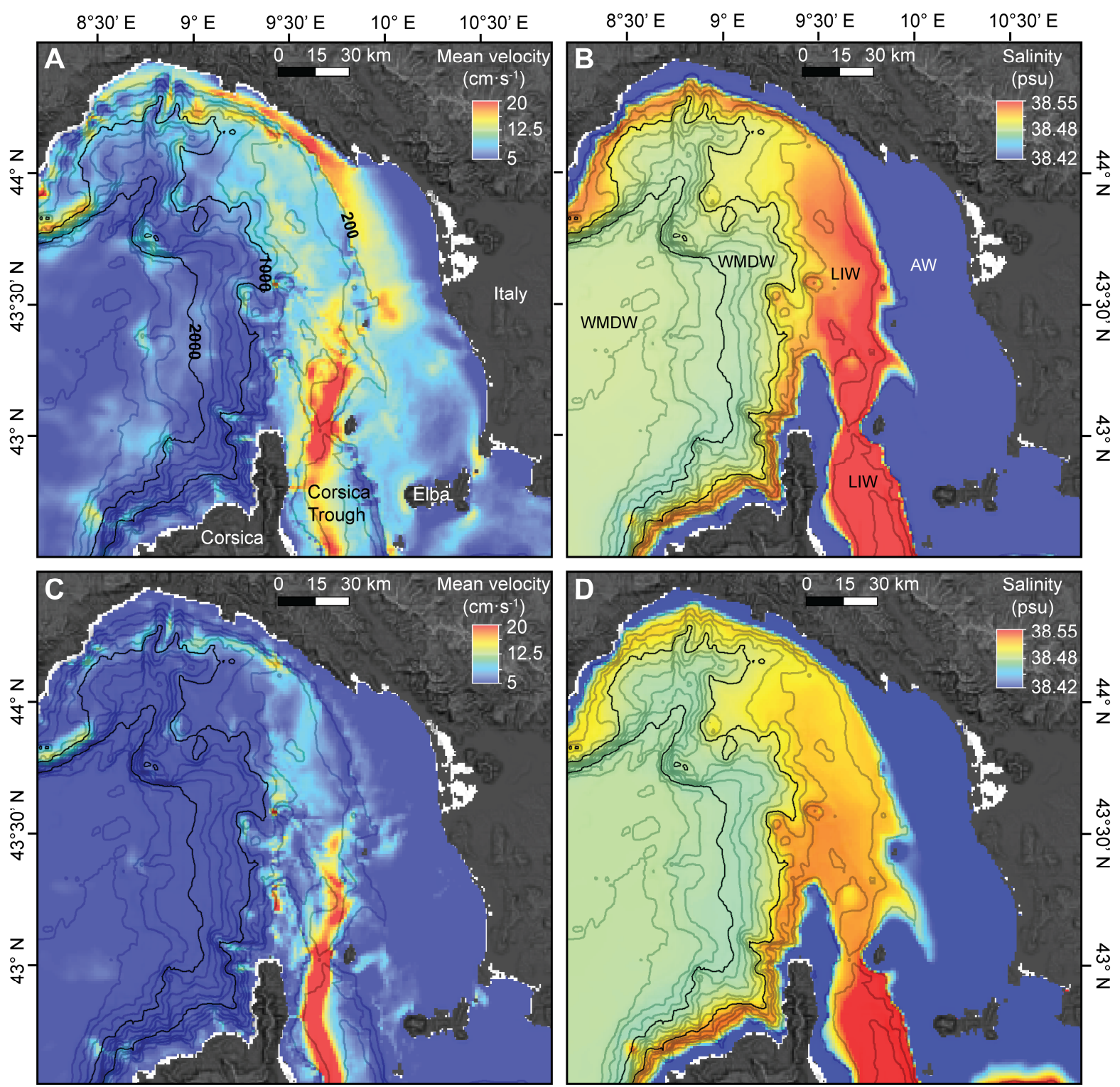


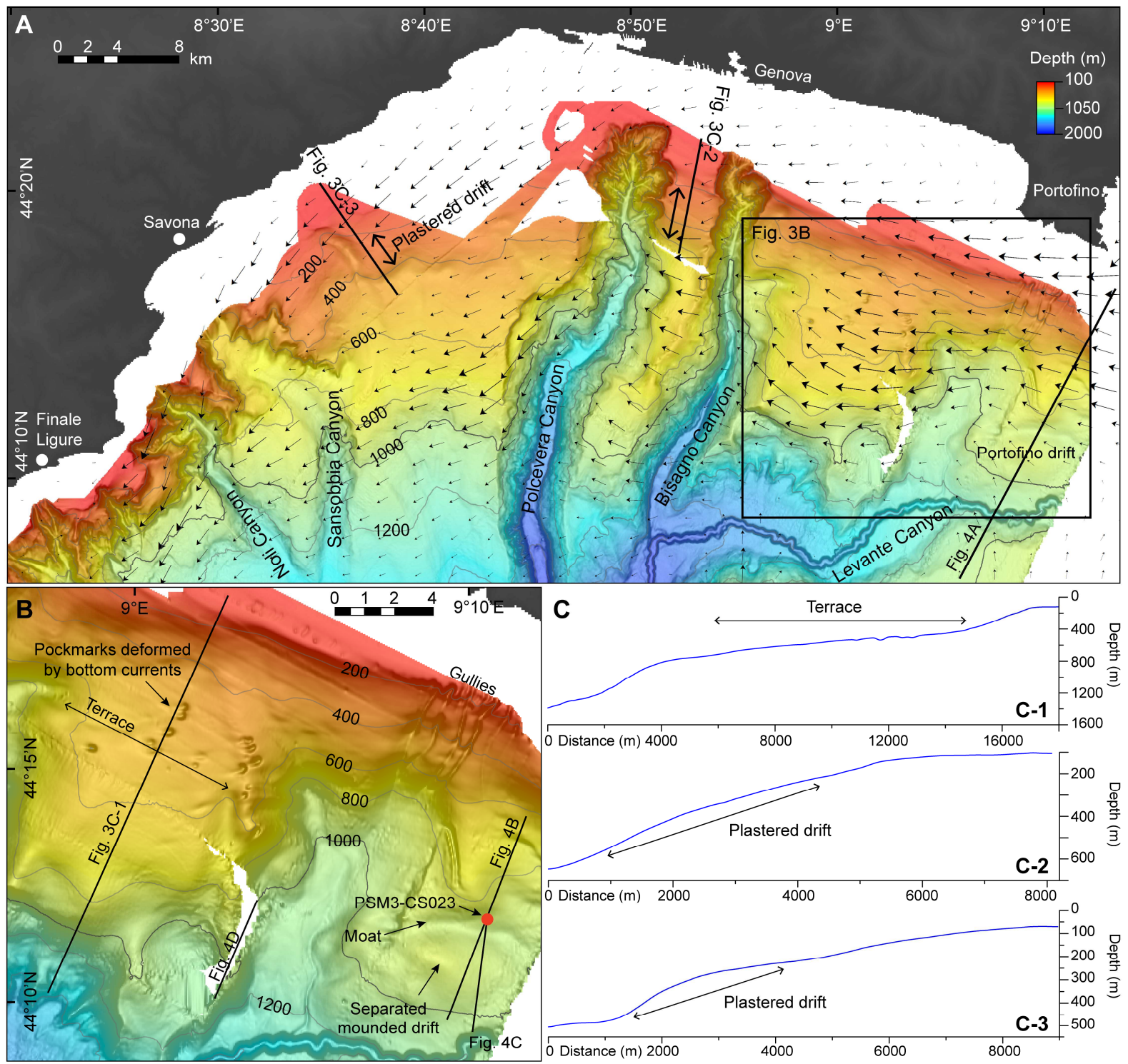



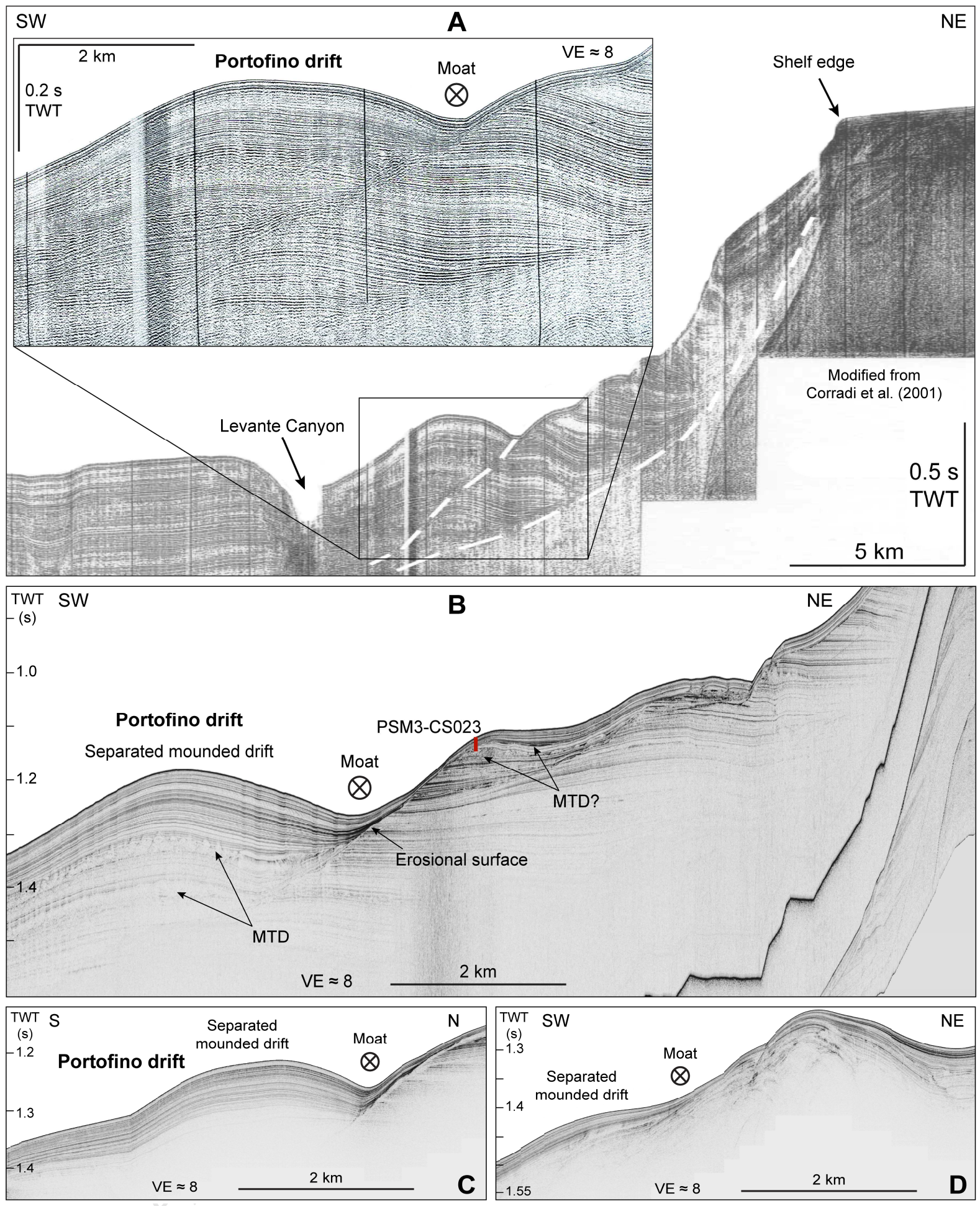


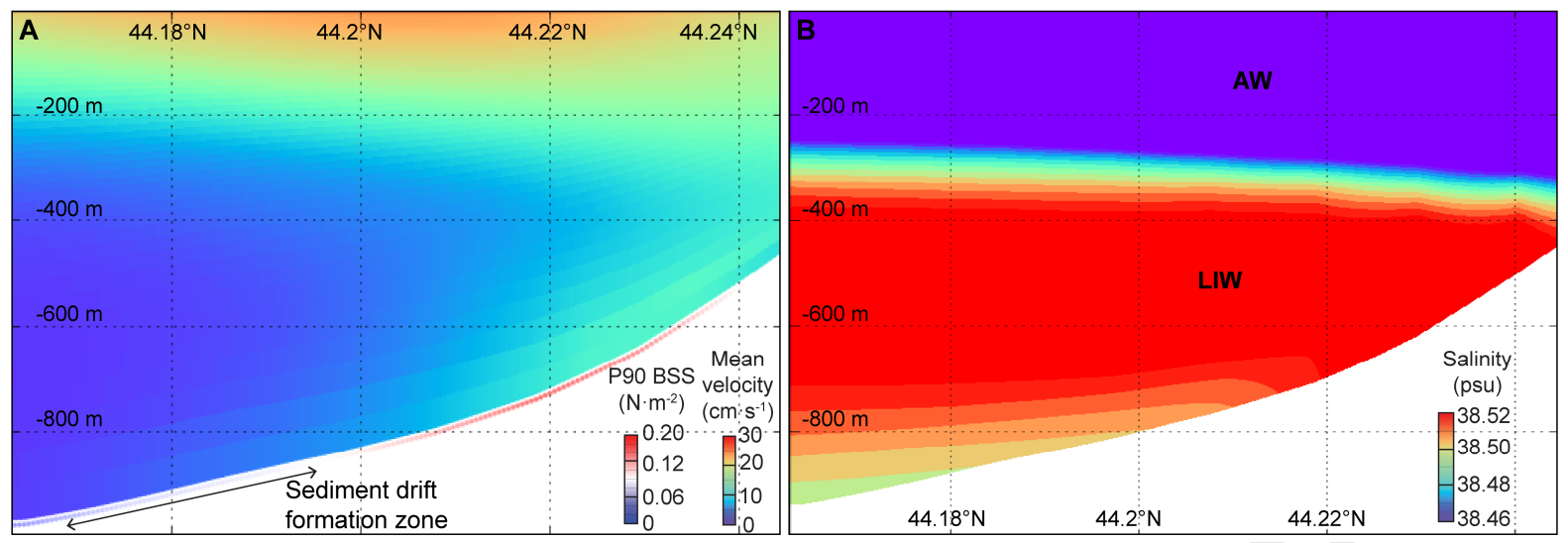


A

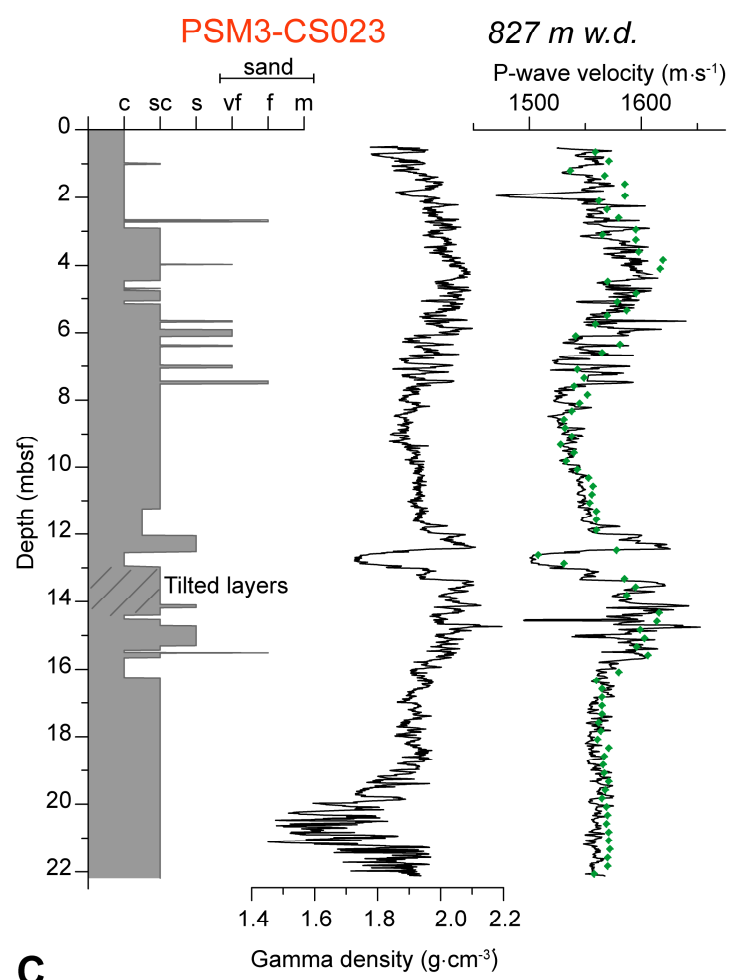

B

Grain-size mass frequency $(\mu \mathrm{m})$

PSM3-CS009 Gamma density $\left(\mathrm{g} \cdot \mathrm{cm}^{-3}\right) \quad$ P-wave velocity $\left(\mathrm{m} \cdot \mathrm{s}^{-1}\right)$

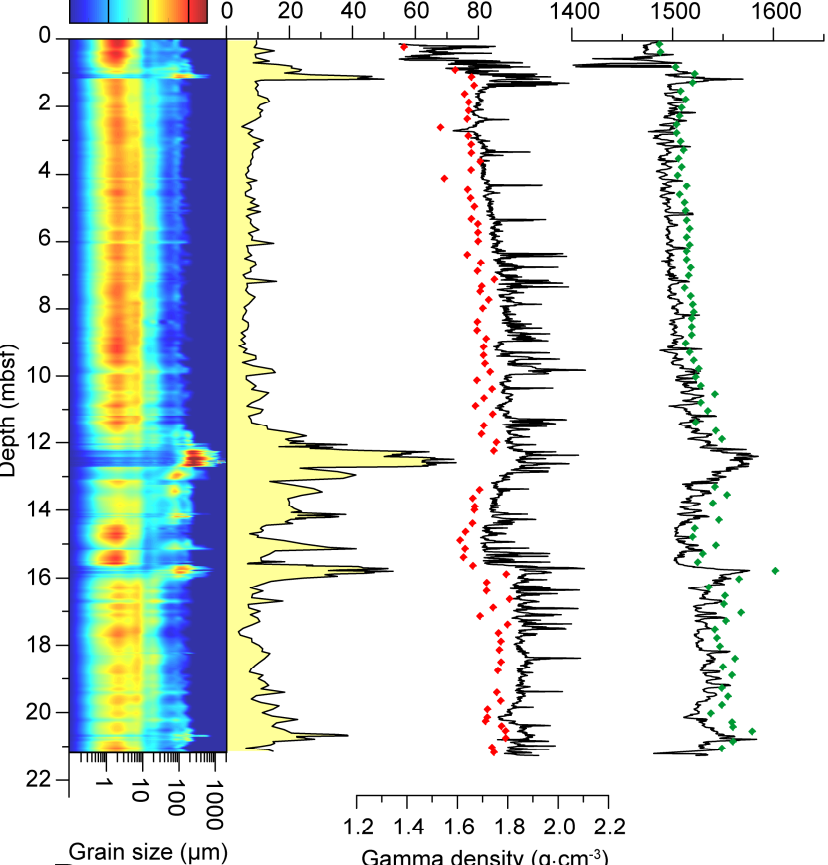

Grain size $(\mu \mathrm{m}) \quad$ Gamma density $\left(\mathrm{g} \cdot \mathrm{cm}^{-3}\right)$
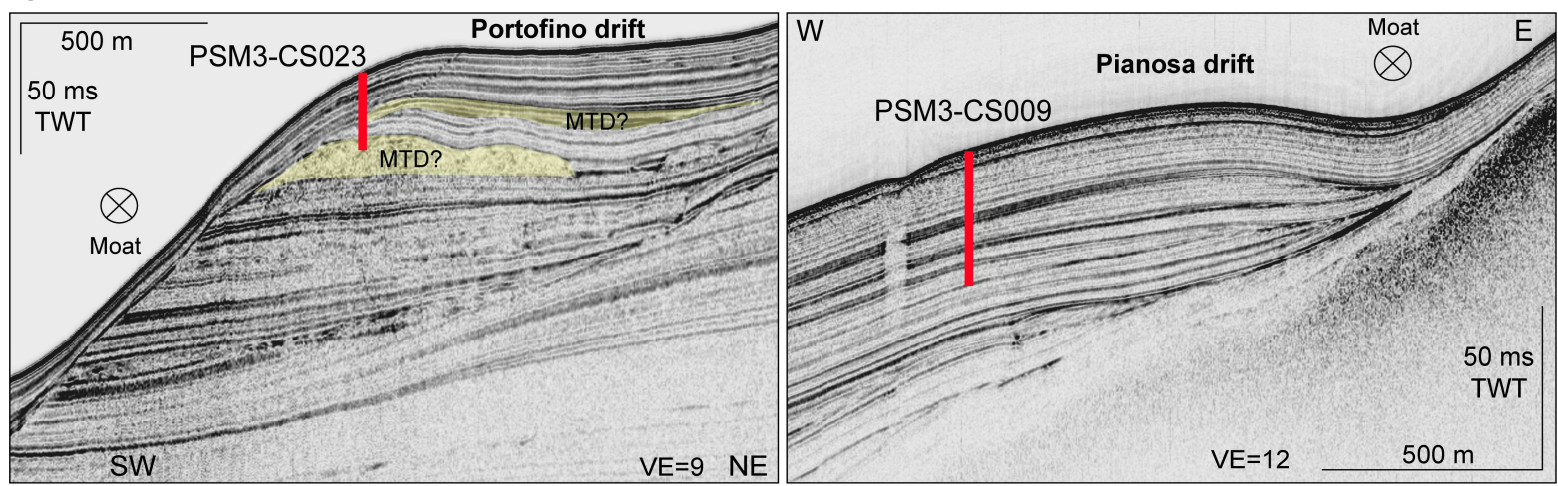